\title{
Robot-assisted nephroureterectomy: current perspectives
}

\author{
This article was published in the following Dove Press journal: \\ Robotic Surgery: Research and Reviews \\ 4 July 2016 \\ Number of times this article has been viewed
}

\author{
Xin Ling Teo \\ Sey Kiat Lim \\ Department of Urology, Changi \\ General Hospital, Singapore
}

Correspondence: Sey Kiat Lim Department of Urology, Changi General Hospital, 2 Simei Street 3, Singapore 529889

Tel +6567888833

Fax +65 67880933

Email Terence_lim@cgh.com.sg
Abstract: Robot-assisted surgery was just a medical curiosity until the development of the da Vinci robotic system, and since then, it has become a widely accepted surgical treatment for many urological conditions such as prostate carcinoma and renal cell carcinoma. With the increase in the number of urologists using the robot and the improvement in surgeon experience, the use of the robot has been expanded to include performing radical nephroureterectomy (NU) for the treatment of primary upper tract urothelial carcinoma. We performed a literature review on robot-assisted laparoscopic NU with the aim of providing a current perspective on robot-assisted laparoscopic NU for the management of upper tract urothelial carcinoma. Surgical technique, perioperative outcomes, and oncological outcomes are discussed.

Keywords: robot, nephroureterectomy, urothelial carcinoma

\section{Introduction}

Primary upper tract urothelial carcinoma (UTUC) is an uncommon entity. It accounts for $\sim 5 \%$ of all renal and urothelial malignancies, with most of the tumors arising from the renal pelvis. As such, patterns of care and optimal management of UTUC are far less studied when compared with urothelial carcinoma of the bladder. Nephroureterectomy (NU) with bladder cuff excision is considered the gold standard for the management of UTUC. It involves en bloc dissection of the kidney, distal ureter, and bladder cuff. Laparoscopic NU was introduced by Clayman et al in 1991, ${ }^{1}$ providing a safe, yet minimally invasive, option when compared to open surgery. However, it remains a surgery with many technical challenges and often requires high levels of laparoscopic skills. This is especially so if the tumor is located in the distal third of the ureter due to the increased difficulty of the management of bladder cuff.

With the use of the da Vinci robotic system (Intuitive Surgical, Sunnyvale, CA), challenges and limitations associated with pure laparoscopy surgery are alleviated, while maintaining the benefits of minimally invasive surgery. Apart from improved dexterity while operating, the Endowrist technology of robotic instruments provides a greater range of motion as compared to the human hand. Further advantages include tremor filtration and better three-dimensional visualization with up to $10 \times$ magnification. Many robot-assisted laparoscopic NU (RALNU) techniques, performed using the da Vinci robotic system, have been described. In the early era, RALNU was performed using a combination of robotic assistance with either the laparoscopic or open approach. This eventually evolved to performing the entire surgery robotically, 
but requiring repositioning of the patient or redocking of the robot. With advances in technology of the robotic system and improvement in techniques, RALNU is now performed in many centers using techniques that do not require intraoperative patient repositioning or robot redocking. In this article, we aim to provide a current perspective on RALNU for the management of UTUC, with a discussion on the surgical techniques of RALNU and the role of lymph node dissection as well as their perioperative and oncological outcomes.

\section{Materials and methods}

Using the keywords laparoscopic NU, bladder cuff, distal ureter, urothelial carcinoma, and/or robotic, we performed a literature review on the available literature on medical databases (PubMed/Medline) between January 2000 and December 2015. There were a total of 17 studies identified that reported their center's techniques of RALNU, perioperative outcomes, or oncological outcomes.

\section{Surgical techniques}

Radical NU is considered the standard treatment for UTUC; however, in the selected cases of low-grade unifocal disease, nephron-sparing surgery may be attempted. The operative details of studies on RALNU are summarized in Table 1.

\section{Positioning of patients}

RALNU or conventional laparoscopic NU can be performed via a transperitoneal or retroperitoneal access. Regardless of the approach, patients are usually positioned in the lateral flank position for this surgery so as to allow the peritoneal contents to fall forward for better surgical exposure and access to the kidney. This is seen in all the studies reviewed, which reported either a lateral flank or a modified lateral flank positioning at the beginning of the surgery. ${ }^{2-18}$ In earlier studies, ${ }^{15,17,18}$ surgeries performed included either a combination of the robotic approach for the nephrectomy followed by the open approach for complete excision of the distal ureter and bladder cuff or the use of laparoscopy for the initial nephrectomy before using robotic assistance for the management of the distal ureter and bladder cuff. However, this required patient repositioning from the lateral flank to the lithotomy position. This gradually evolved into RALNU being performed entirely robotically; however, this still involved repositioning the patient intraoperatively and robot redocking to manage the distal ureter and bladder cuff. . $^{2,5,13,14}$ With the improvement in technology and the introduction of the newer generation, the da Vinci Xi system allows for multi-quadrant surgeries to be performed through a rotating boom and $8 \mathrm{~mm}$ endoscope that can be used in any of the robotic ports; it may now be possible to complete the whole RALNU without any intraoperative patient repositioning or robot redocking at all. ${ }^{2-4,6-12,16}$

\section{Port placement templates}

Proper port placement is an essential key step toward a successful RALNU, as the ports should ideally allow for access to both the retroperitoneum and the pelvis. This is a major limitation to the use of the robotic system for performing a radical NU, and many surgeons adopted various different approaches and strategies to overcome this problem. This included completing the distal ureterectomy via the open or laparoscopic approach, or repositioning of the robot and/or the patient. Intraoperative patient repositioning or redocking of the robot has been shown to add, on average, an additional 30-60 minutes to the operative time. ${ }^{19}$ Newer techniques have described port placement schemes that allow instrument access to the kidney and subsequently the bladder, while avoiding instrument clashing, and this would make patient repositioning and robot redocking unnecessary. Rose et al ${ }^{18}$ described a hybrid port technique that allows the hybrid port to accommodate robotic instruments and also allows the assistant direct access for clipping and stapling of the renal vessels with endovascular staplers. Eun et al ${ }^{16}$ described a "baseball diamond" four-port strategy to allow instrument access to an entire ipsilateral urinary tract in one operating session without repositioning the patient and redocking the robot. In addition, they also described a pivoting triangle maneuver that improved instrument depth during deep pelvic dissection, providing up to $8 \mathrm{~cm}$ of extended reach to facilitate deeper access into the pelvis. This was initially performed on porcine and cadaveric models, and then successfully performed uneventfully on a human patient. Lee et $\mathrm{al}^{11}$ described their unique port placement technique that uses the modified paramedian line technique, which allows the surgery to be completed without requiring port reassignment, patient repositioning, or robotic redocking. Badani et $\mathrm{al}^{7}$ described a modified port placement technique that allows the surgeon to approach both proximally up to the superior pole of the kidney and the areas distal to the ureteric insertion into the bladder without clashing of the robotic arms. With this port placement strategy, the surgery can be performed with only a single instrument switch, without the need for patient repositioning. Various other centers also echoed this feasibility of performing a robotic NU in one setup by describing their own technique with various differing port configurations. We have included schematic diagrams (Figures 1 and 2) of port 


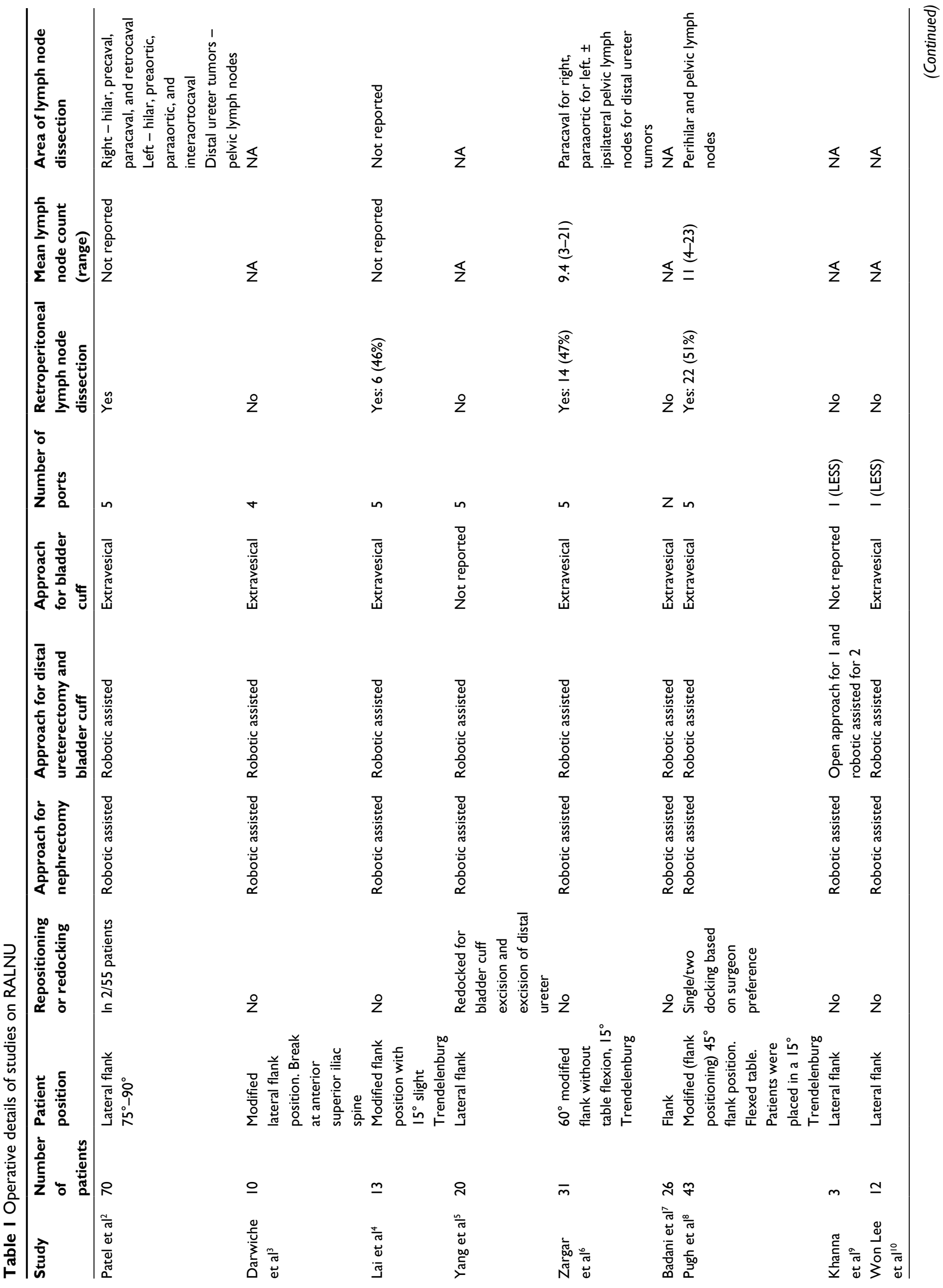




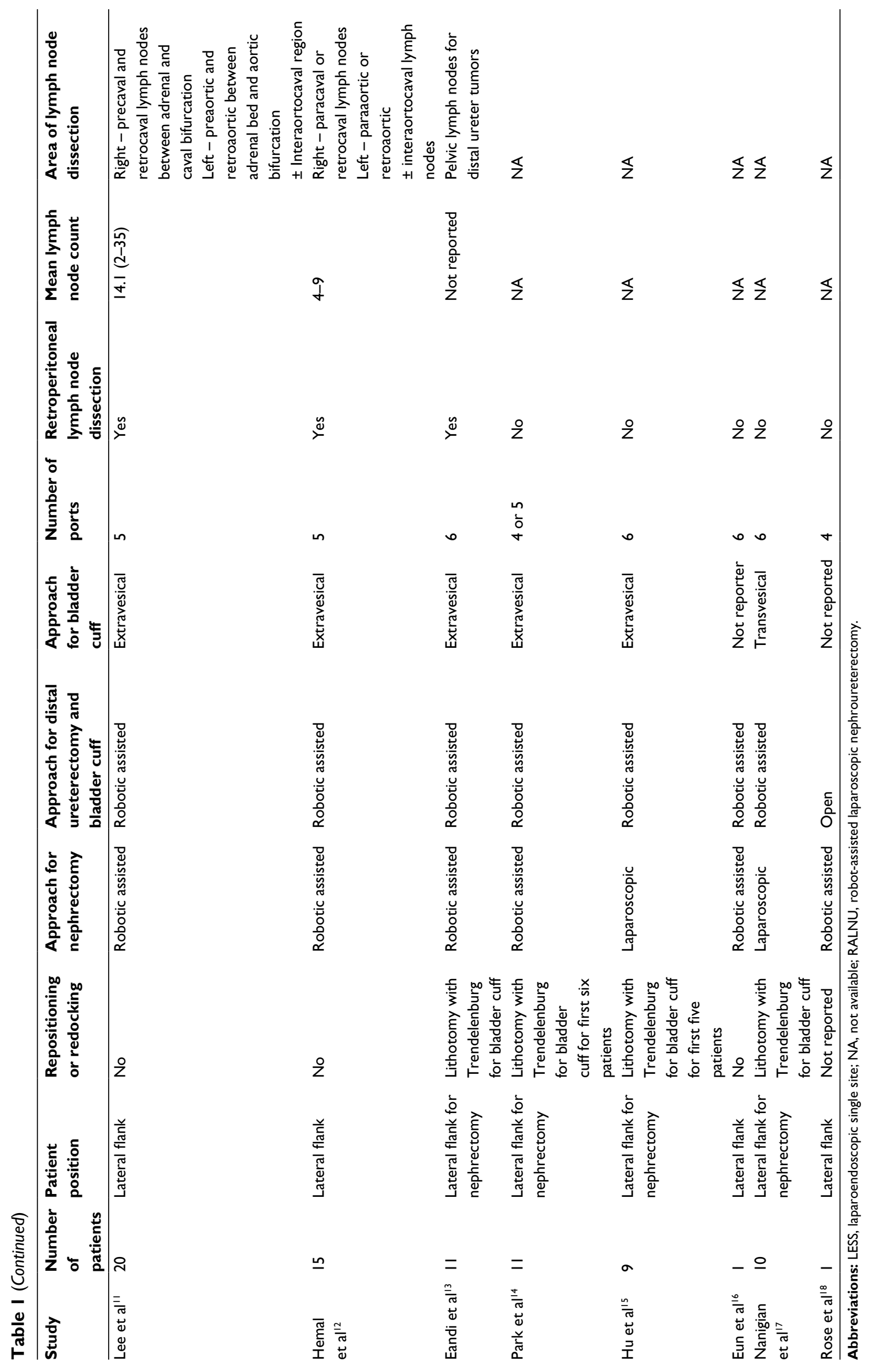




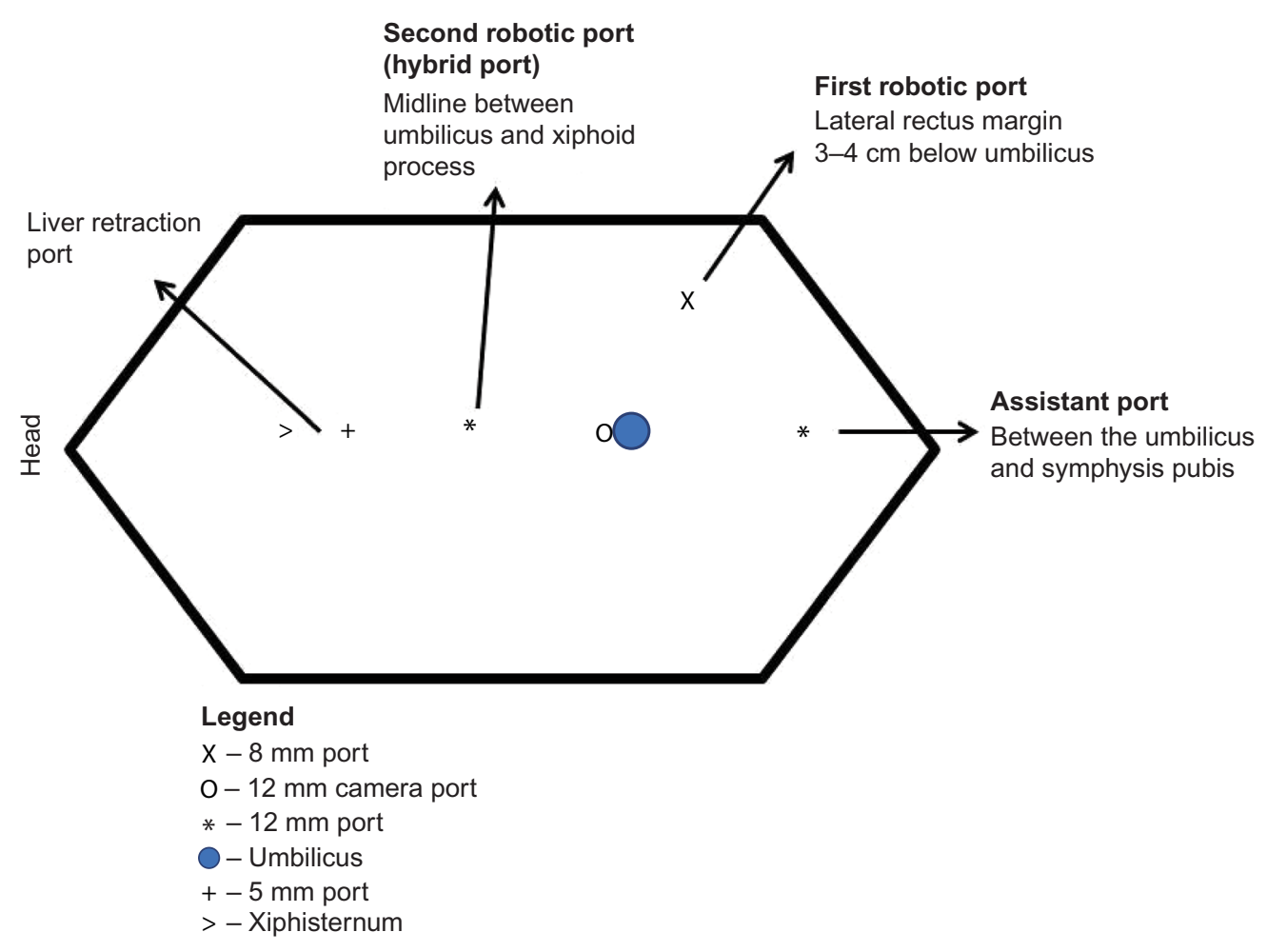

Figure I Right nephrectomy port placement.

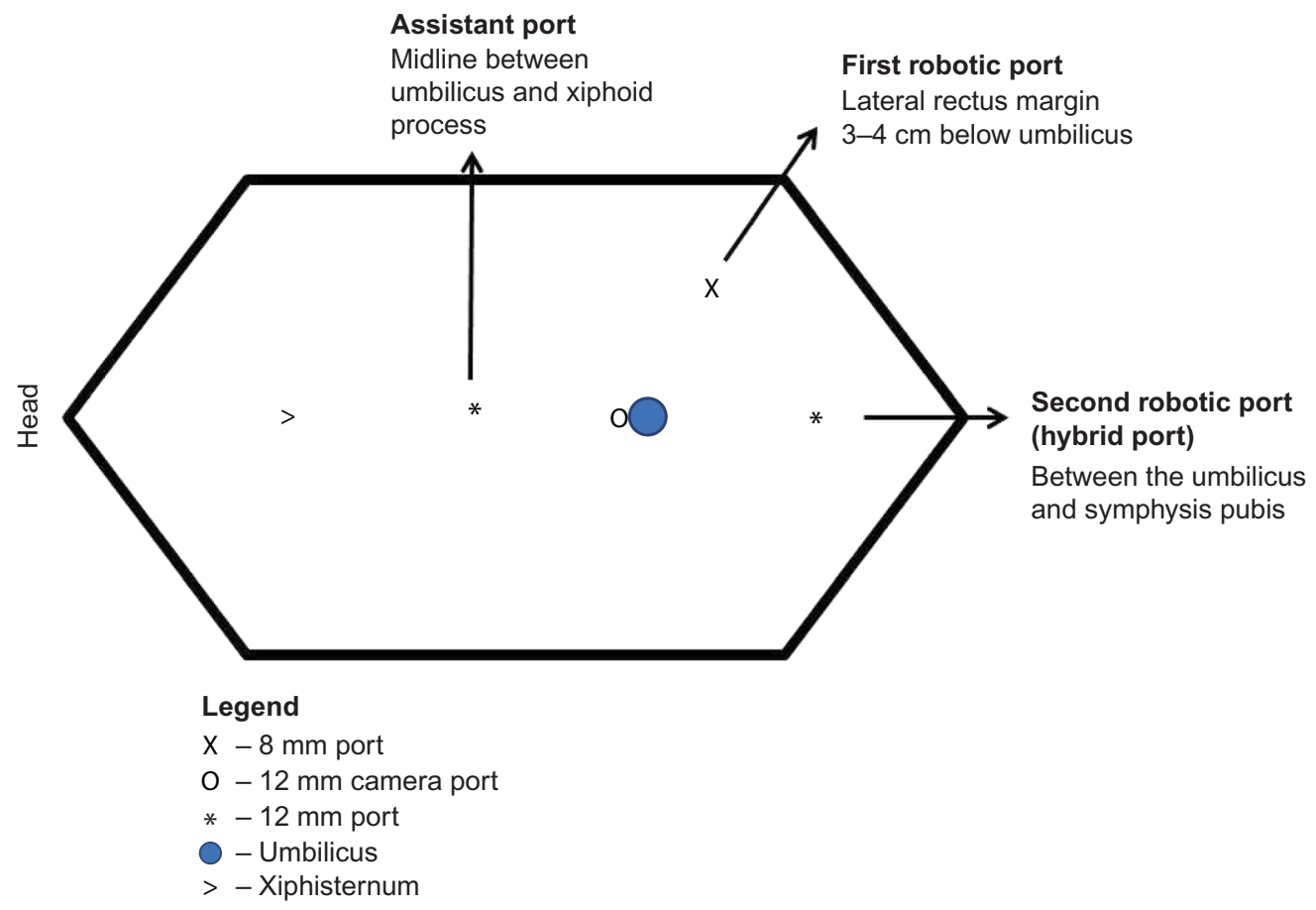

Figure 2 Right ureterectomy port placement.

placement for right RALNU in our institution using the da Vinci Si system, adopting a similar port placement strategy as described by Park et al. ${ }^{14}$ Figure 1 shows the port position for the nephrectomy part of the surgery. The distance between the camera and both robotic port measures $\sim 8 \mathrm{~cm}$. After completion of the robotic nephrectomy, the configurations of robotic ports for distal ureterectomy are changed as shown in Figure 2.

Two centers recently published their experience with performing RALNU on the da Vinci Xi system. Darwiche et $\mathrm{al}^{3}$ utilized four $8 \mathrm{~mm}$ robotic ports positioned in an oblique straight line starting with a robotic port located two finger 
breadths below the costal margin just lateral to the rectus abdominis muscle with a minimum distance of $6-8 \mathrm{~cm}$ between the ports. In addition, they used a $12 \mathrm{~mm}$ assistant port placed closer to the midline and between the two most cephalad robotic ports with or without an additional $5 \mathrm{~mm}$ port used for liver retraction for right-sided RALNU. Patel et $\mathrm{al}^{2}$ described their center's transition from the da Vinci Si to the da Vinci Xi system and described a port placement configuration on the da Vinci Xi which utilizes four $8 \mathrm{~mm}$ robotic ports placed linearly along the lateral border of the rectus muscle in addition to one $12 \mathrm{~mm}$ assistant port placed $2-3 \mathrm{~cm}$ cranial to umbilicus.

Most reported techniques require four to six ports to perform RALNU, although robot-assisted laparoendoscopic single-site (LESS) RALNU has also been reported in a few centers. In comparison to conventional multiport technique, the LESS RALNU was found to compare well in terms of oncological and perioperative outcomes, although it might result in greater intraoperative blood loss when compared to intraoperative blood loss reported in NU series performed with other approaches. ${ }^{20}$ The use of a robotic system can alleviate some of the problems inherent with the technical difficulties associated with laparoscopic LESS NU. These include a reduction in the triangulation afforded in standard laparoscopy and the internal clashing of instruments. However, LESS RALNU remains a technically challenging surgery that has been reported only in a few centers.

\section{Role of lymphadenectomy}

The overall incidence of lymph node involvement for UTUC has been reported to be between $12 \%$ and $25 \%$, with disease stage and grade correlating with an increased risk of node involvement. Involvement of regional lymph nodes has been found to be a significant predictor of patient outcomes, especially in cases of muscle invasive disease. However, the role of lymphadenectomy has not been clearly defined.

Roscigno et $\mathrm{al}^{21}$ found that an accurate lymphadenectomy can remove nodal micrometastases that were not identified on routine pathologic examination, in turn improving locoregional control and cancer-specific survival. Another study also found that removing eight or more lymph nodes was predictive for cause-specific mortality for UTUC in those with pN0 disease. ${ }^{22}$ Template-based lymphadenectomy has been shown to reduce the risk of regional node recurrence in patients with renal pelvis urothelial carcinoma with improved survival. ${ }^{23}$ Despite retrospective evidence indicating that a thorough regional lymph node dissection can provide vital prognostic information and potential therapeutic benefit in patients with limited nodal disease, the concept of meticulous lymph node dissection for UTUC during NU has not been consistently adopted by urologists around the world, ${ }^{24}$ and the benefit of lymph node dissection during NU remains controversial. ${ }^{25}$

Guidelines currently recommend lymphadenectomy to be performed for patients with muscle invasive disease. However, recommendation grades are low. ${ }^{26,27} \mathrm{~A}$ meta-analysis performed confirmed a benefit of lymph node dissection only in patients with muscle invasive tumors ${ }^{28}$ with other large cohort retrospective studies supporting this finding. ${ }^{29}$

Regional lymph node dissection can be performed using the robot, in a similar fashion to the laparoscopic approach, but with all the advantages of the robotic system, primarily better ergonomics with improved dexterity and freedom of movements. This may account for the findings of Pearce et $\mathrm{al}^{30}$ who showed that the robotic approach independently increased the odds of lymphadenectomy performance nearly twofold when compared to the open approach, whereas the laparoscopic approach reduced the odds of lymphadenectomy performance. In addition, when RALNU was performed, the median lymph node yields were higher for the robotic approach. ${ }^{31}$

Most centers perform the lymphadenectomy with similar templates. Precaval, paracaval, and/or retrocaval nodes were usually removed in right-sided tumors, while preaortic, paraaortic, and/or retroaortic nodes were usually removed in left-sided tumors. Patel et $\mathrm{al}^{2}$ also included perihilar lymphadenectomy, while Pugh et $\mathrm{al}^{8}$ performed only perihilar and pelvic lymphadenectomy based on clinical stage, grade preoperative imaging characteristics, and intraoperative findings. Interaortocaval nodes were removed only if indicated. Pelvic lymph node dissection was performed for distal ureteric tumors.

\section{Management of the distal ureter and bladder cuff}

En bloc dissection of the kidney, distal ureter, and bladder cuff is the preferred method for treating UTUC, regardless of the approach, and total excision is mandatory due to the increased risk of tumor recurrence. In situations with incomplete removal of the upper tract resulting in a residual stump, the risk of tumor recurrence within the residual stump is often cited as between $30 \%$ and $64 \% .{ }^{32}$ Multiple techniques have been described that can be broadly classified into extravesical, transvesical, or endoscopic approaches based on their approach. All these can be performed during RALNU, though the open resection technique remains the gold standard management of the distal ureter.

Each technique of the distal ureter management has inherent advantages and disadvantages, and the current literature has not demonstrated the superiority of one technique 
over the other. Li et $\mathrm{al}^{33}$ reported comparable oncological outcomes with three techniques of bladder cuff excision (intravesical, extravesical, and transurethral incision) in a retrospective single-center study. While Walton et a ${ }^{34}$ found that transvesical endoscopic ureteral detachment has rates of resection site recurrence that are not different from the gold standard, especially for patients with pelvicaliceal tumors, a multicenter retrospective study however found that the endoscopic approach was associated with a higher rate of intravesical recurrence compared to the transvesical and intravesical approaches. There was, however, no difference in the recurrence-free survival, cancer-specific survival, and overall survival between the different bladder cuff approaches..$^{35}$ Laparoscopic extravesical stapling has been shown to have an increased positive margin rate and local recurrence rate and decreased recurrence free intervals when compared to the various methods of distal ureteric excision. ${ }^{36}$ Tsivian et $\mathrm{al}^{37}$ then described a modified technique of laparoscopic stapling which utilizes a $10 \mathrm{~mm}$ ligasure atlas, and with this technique, they found no reports of local recurrence after 1 year of surgery in a small cohort of patients.
Phé et $\mathrm{al}^{36}$ found that the robot-assisted laparoscopic approach for the management of the distal ureter and bladder cuff is a safe oncological approach. Replicating the open techniques, laparoscopic extravesical or transvesical excision of distal ureter and bladder cuff combines the benefit of minimally invasive surgery with similar oncological efficacy as an open bladder cuff excision. ${ }^{38}$ With features facilitating intracorporeal stitching, these techniques, while highly challenging when performed laparoscopically, are less daunting when performed with the robot. In all the RALNU studies that described their distal ureterectomy techniques, most of them performed it via the extravesical or transvesical approach.

\section{Perioperative outcomes}

The perioperative outcomes of RALNU are shown in Table 2.

Studies not requiring patient repositioning or redocking of the robot during the procedure generally reported shorter operative timings. Park et $\mathrm{al}^{14}$ reported their initial hybrid port technique for $\mathrm{NU}$ without redocking of the robot and the total operative time was reduced by $\sim 54$ minutes compared to the approach requiring relocation of the robot between

Table 2 Perioperative outcomes of studies on RALNU

\begin{tabular}{|c|c|c|c|c|c|c|c|c|}
\hline Study & $\begin{array}{l}\text { Number of } \\
\text { patients }\end{array}$ & $\begin{array}{l}\text { Follow- } \\
\text { up period } \\
\text { (months) }\end{array}$ & $\begin{array}{l}\text { Mean } \\
\text { operative } \\
\text { time } \\
\text { (minute) }\end{array}$ & $\begin{array}{l}\text { Estimated } \\
\text { blood loss } \\
(\mathrm{mL})\end{array}$ & $\begin{array}{l}\text { Hospital } \\
\text { stay (day) }\end{array}$ & $\begin{array}{l}\text { Requiring } \\
\text { blood } \\
\text { transfusion } \\
\text { (number of } \\
\text { patients) } \\
\end{array}$ & $\begin{array}{l}\text { Intraoperative } \\
\text { complications }\end{array}$ & $\begin{array}{l}\text { Post-op } \\
\text { complications }\end{array}$ \\
\hline Patel et $\mathrm{al}^{2}$ & 70 & Not reported & $154(110-245)$ & $120(50-200)$ & $2(I-3)$ & Nil & $\begin{array}{l}\text { Hypotension } \\
\text { requiring } \\
\text { vasopressors } \\
\text { intraoperatively }\end{array}$ & $\begin{array}{l}\text { One patient had delayed } \\
\text { return of bowel function, } \\
\text { one developed abdominal } \\
\text { abscess requiring } \\
\text { percutaneous drainage, } \\
\text { one patient developed } \\
\text { chylous ascites requiring } \\
\text { percutaneous drainage }\end{array}$ \\
\hline $\begin{array}{l}\text { Darwiche } \\
\text { et } \mathrm{al}^{3}\end{array}$ & 10 & $4.3(0.5-7)$ & $184(140-300)$ & $12 \mid(60-300)$ & 2.4 & Nil & Nil & $\begin{array}{l}\text { One patient had } \\
\text { pulmonary embolism. One } \\
\text { patient with preexisting } \\
\text { stage } 4 \text { chronic kidney } \\
\text { disease required } \\
\text { hemodialysis }\end{array}$ \\
\hline Lai et $\mathrm{al}^{4}$ & 13 & $14(I-38)$ & $129(105-150)$ & $128(30-500)$ & $7(4-14)$ & Not reported & Nil & $\begin{array}{l}\text { One patient had } \\
\text { pneumonia. One patient } \\
\text { had brachial nerve injury }\end{array}$ \\
\hline Yang et $\mathrm{al}^{5}$ & 20 & $14.7(2-34)$ & $\begin{array}{l}251.7 \\
(110-540)\end{array}$ & $50(10-200)$ & $6.7(4-12)$ & Not reported & Nil & Nil \\
\hline $\begin{array}{l}\text { Zargar } \\
\text { et al }{ }^{6}\end{array}$ & 31 & $8(0-32)$ & 300 minutes & $\begin{array}{l}\text { Median } \\
\text { (interquartile } \\
\text { range) } 200 \\
(100-375)\end{array}$ & $\begin{array}{l}\text { Median } 5 \\
\text { (interquartile } \\
\text { range 3-6) }\end{array}$ & Nil & Nil & $\begin{array}{l}\text { Four grade I, one grade } \\
2 \text { (Clostridium difficile } \\
\text { infection), and one grade } 3 \\
\text { (local collection requiring } \\
\text { percutaneous drainage) }\end{array}$ \\
\hline
\end{tabular}

(Continued) 
Table 2 (Continued)

\begin{tabular}{|c|c|c|c|c|c|c|c|c|}
\hline Study & $\begin{array}{l}\text { Number of } \\
\text { patients }\end{array}$ & $\begin{array}{l}\text { Follow- } \\
\text { up period } \\
\text { (months) }\end{array}$ & $\begin{array}{l}\text { Mean } \\
\text { operative } \\
\text { time } \\
\text { (minute) }\end{array}$ & $\begin{array}{l}\text { Estimated } \\
\text { blood loss } \\
(\mathrm{mL})\end{array}$ & $\begin{array}{l}\text { Hospital } \\
\text { stay (day) }\end{array}$ & $\begin{array}{l}\text { Requiring } \\
\text { blood } \\
\text { transfusion } \\
\text { (number of } \\
\text { patients) }\end{array}$ & $\begin{array}{l}\text { Intraoperative } \\
\text { complications }\end{array}$ & $\begin{array}{l}\text { Post-op } \\
\text { complications }\end{array}$ \\
\hline $\begin{array}{l}\text { Badani } \\
\text { et } \mathrm{al}^{7}\end{array}$ & 26 & $7.8(2-17)$ & $230(128-310)$ & $66(25-100)$ & $2(1-15)$ & $\mathrm{Nil}$ & Nil & Nil \\
\hline Pugh et $\mathrm{al}^{8}$ & 43 & $9.6(2-36)$ & $247(128-390)$ & $13 \mid(10-500)$ & $3(2-87)$ & $\mathrm{I}$ & Nil & $\begin{array}{l}\text { One patient had } \\
\text { postoperative bleeding, } \\
\text { one patient had } \\
\text { emergency splenectomy } \\
\text { for splenic bleeding, two } \\
\text { patients had pneumonia, } \\
\text { two patients had transient } \\
\text { rhabdomyolysis }\end{array}$ \\
\hline $\begin{array}{l}\text { Khanna } \\
\text { et } \text { al }^{9}\end{array}$ & 3 & 17.8 & 300 & 183 & 3.3 & Not reported & $\begin{array}{l}\text { One conversion } \\
\text { to standard } \\
\text { laparoscopy }\end{array}$ & $\begin{array}{l}\text { One patient had } \\
\text { postoperative ileus }\end{array}$ \\
\hline $\begin{array}{l}\text { Won Lee } \\
\text { et } \mathrm{al}^{10}\end{array}$ & 12 & Not reported & 227 & 248 & 4 & 2 & Nil & Nil \\
\hline Lee et $\mathrm{al}^{\prime \prime}$ & 20 & 13.5 & 161.3 & 98.8 & 3 & 2 & Nil & $\begin{array}{l}\text { One patient had post-op } \\
\text { ileus and one patient had } \\
\text { pneumonia }\end{array}$ \\
\hline $\begin{array}{l}\text { Hemal } \\
\text { et } \mathrm{al}^{12}\end{array}$ & 15 & Not reported & 184 & 103 & 2.7 & Not reported & Nil & $\mathrm{Nil}$ \\
\hline $\begin{array}{l}\text { Eandi } \\
\text { et } \mathrm{al}^{13}\end{array}$ & II & 15.2 & 326 & 200 & 4.7 & I & Nil & $\begin{array}{l}\text { Two patients had } \\
\text { postoperative ileus. One } \\
\text { patient had pulmonary } \\
\text { embolism. One patient } \\
\text { had acute and chronic } \\
\text { renal insufficiency } \\
\text { secondary to dehydration } \\
\text { I week after discharge }\end{array}$ \\
\hline \multirow[t]{2}{*}{$\begin{array}{l}\text { Park } \\
\text { et } \mathrm{al}^{14}\end{array}$} & $\begin{array}{l}\text { Six patients } \\
\text { performed } \\
\text { with standard } \\
\text { port } \\
\text { configuration }\end{array}$ & Not reported & 247 & 107 & 7 & Not reported & Nil & Nil \\
\hline & $\begin{array}{l}\text { Five patients } \\
\text { performed } \\
\text { with hybrid } \\
\text { configuration }\end{array}$ & Not reported & 193 & 270 & 8.4 & Not reported & Nil & Nil \\
\hline Hu et $a^{15}$ & 9 & 13.2 & 303 & 211 & 2.3 & I & Nil & Nil \\
\hline Eun et $\mathrm{al}^{16}$ & 1 & Not reported & 250 & 100 & 7 & Not reported & Nil & $\begin{array}{l}\text { Hypoxia secondary to } \\
\text { mucus plugging }\end{array}$ \\
\hline $\begin{array}{l}\text { Nanigian } \\
\text { et } \text { al }^{17}\end{array}$ & 10 & 6 & 264 & Not reported & 3 & Not reported & Not reported & Nil \\
\hline $\begin{array}{l}\text { Rose } \\
\text { et } \mathrm{al}^{18}\end{array}$ & 2 & 3 & 182.5 & 75 & 6 & Not reported & Nil & Nil \\
\hline
\end{tabular}

Note: Data shown as mean (range) or $\mathrm{n}$.

Abbreviation: RALNU, robot-assisted laparoscopic nephroureterectomy.

the patient's legs with other studies supporting this finding. ${ }^{39}$ Interestingly, few studies when comparing RALNU with hand-assisted NU or laparoscopic NU did not show a significant shorter operative time, ${ }^{31,39}$ possibly because the studies were comparing an early RALNU experience with a well-experienced laparoscopic practice with operative times ranging from 255 minutes to 298 minutes. A meta-analysis comparing laparoscopic and open NU showed that RALNU operative times were comparable to open NU, but shorter than laparoscopic NU..$^{40}$ The operative times of the RALNU series are also comparable to published open series.

One of the benefits of minimally invasive surgery is the reduced intraoperative blood loss, which is primarily due to the tamponade from the pneumoperitoneum as well 
as improved visualization of the anatomy. In the RALNU studies, published estimated blood loss volumes ranged from $66 \mathrm{~mL}$ to $270 \mathrm{~mL}$ with recent studies trending toward a lower estimated blood loss. Nevertheless, this appears to be lower than the mean estimated blood loss in laparoscopic NU and open radical NU cited in a meta-analysis comparing outcomes of laparoscopic NU and open radical NU. ${ }^{40}$ There was, however, no difference in the number of blood transfusions required when population-based assessments on perioperative outcomes were performed. ${ }^{41}$ Possible reasons for the lower estimated blood loss include a reduction in the operative time, better visualization of the vasculature, and improved ergonomics and ease of performing the surgery with the aid of the robot.

The mean hospital stay for the published RALNU studies was 2-8.4 days with more contemporary series generally reporting a shorter mean length of stay of 2-3 days. Population-based assessments reported no statistical difference between the average length of stay for RALNU and laparoscopic NU; however, patients treated with RALNU had a lower rate of prolonged length of stay than laparoscopic NU. ${ }^{41}$ Patients undergoing RALNU were also shown to be significantly less likely to have any complication during hospitalization compared to patients receiving laparoscopic NU. ${ }^{41}$

\section{Oncological outcomes}

The robot-assisted approach is a fairly new technique that represents an extension of the laparoscopic technique in helping to overcome the limitations of the laparoscopic approach. However, extrapolation of laparoscopic NU findings to RALNU needs to be cautioned, and long-term survival data are still not available. While intermediate oncological outcomes reported demonstrate satisfactory oncological control, long-term outcomes are still required to assess true efficacy. ${ }^{42}$ Many RALNU studies also have a small number of patients with limited follow-up, making the analysis of oncological outcomes difficult. The oncological outcomes of the studies on RALNU are presented in Table 3.

\section{Recurrence patterns}

Rates of recurrence in the bladder after treatment of primary urinary UTUC have been reported to be $22 \%-47 \%{ }^{26}$ Tumor recurrences in the bladder tend to occur most commonly in

Table 3 Oncological outcomes of studies on RALNU

\begin{tabular}{|c|c|c|c|c|c|}
\hline Study & $\begin{array}{l}\text { Number of } \\
\text { patients }\end{array}$ & $\begin{array}{l}\text { Surgical margins } \\
\text { (numberl } \\
\text { percentage) }\end{array}$ & $\begin{array}{l}\text { Patients with } \\
\text { positive } \\
\text { lymph nodes }\end{array}$ & Intravesical recurrence & Local/distant metastasis \\
\hline Patel et $\mathrm{al}^{2}$ & 70 & $4(7.3 \%)$ & Not reported & Not reported & Not reported \\
\hline Darwiche et $\mathrm{al}^{3}$ & 10 & Negative & NA & Not reported & Not reported \\
\hline Lai et $\mathrm{al}^{4}$ & 13 & $3(23 \%)$ & $2(33 \%)$ & $2(16 \%)$ & $2(15 \%)-$ brain and lung \\
\hline Yang et $\mathrm{al}^{5}$ & 20 & Negative & NA & $\begin{array}{l}3(15 \%) \text { (all superficial } \\
\text { recurrence) }\end{array}$ & $\begin{array}{l}\text { No local metastasis: four distant metastasis } \\
(20 \%) \text {, site of metastases not indicated }\end{array}$ \\
\hline Zargar et $\mathrm{al}^{6}$ & 31 & I (3.2\%) & $2(14 \%)$ & $7(22.6 \%)$ & Four local/distant metastasis \\
\hline Badani et $\mathrm{al}^{7}$ & 26 & Negative & NA & $4(15.4 \%)$ & Not reported \\
\hline Pugh et $\mathrm{al}^{8}$ & 43 & I $(2 \%)$ & $4(18 \%)$ & $6(14 \%)$ & $\begin{array}{l}3(7 \%) \text { - two retroperitoneal, one } \\
\text { contralateral collecting system }\end{array}$ \\
\hline Khanna et $\mathrm{al}^{9}$ & 3 & Negative & Not reported & None & None \\
\hline Won Lee et al ${ }^{10}$ & 12 & Not reported & Not reported & Not reported & Not reported \\
\hline Lee et $\mathrm{al}^{\prime \prime}$ & 20 & I & $3(19 \%)$ & None & $\begin{array}{l}\text { One patient with paraaortic lymph node } \\
\text { recurrence }\end{array}$ \\
\hline Hemal et $\mathrm{al}^{12}$ & 15 & Negative & Not reported & None & None \\
\hline Eandi et $\mathrm{al}^{13}$ & $\mathrm{II}$ & Negative & Not reported & $\begin{array}{l}2(18.1 \%) \text { (one superficial } \\
\text { recurrence and one muscle } \\
\text { invasive recurrence) }\end{array}$ & $\begin{array}{l}2 \text { (one with local recurrence at renal fossa } \\
\text { and one with distant metastases) }\end{array}$ \\
\hline Park et $\mathrm{al}^{14}$ & II & Negative & NA & Not reported & Not reported \\
\hline Hu et $\mathrm{al}^{15}$ & 9 & I & NA & $\begin{array}{l}4(44.4 \%) \text { (three superficial } \\
\text { recurrences and one muscle } \\
\text { invasive recurrence) }\end{array}$ & $\begin{array}{l}\text { One patient with retroperitoneal and liver } \\
\text { metastases }\end{array}$ \\
\hline Eun et $\mathrm{al}^{16}$ & I & Negative & NA & Not reported & Not reported \\
\hline Nanigian et $\mathrm{al}^{17}$ & 10 & Negative & NA & $\begin{array}{l}\text { I (I0\%) (superficial } \\
\text { recurrence) }\end{array}$ & None \\
\hline Rose et $\mathrm{al}^{18}$ & $\mathrm{I}$ & Negative & NA & None & None \\
\hline
\end{tabular}

Abbreviations: NA, not available; RALNU, robot-assisted laparoscopic nephroureterectomy. 
the first 2 years postoperatively, with the recurrence rate gradually decreasing to being minimal after 10 years. ${ }^{43}$ The tendency of UTUC to recur around the wall of cystostomy or the bladder neck, which could have been compromised by the presence of the urethral catheter, ${ }^{44}$ implies that complete excision of the bladder is mandatory for optimal management of UTUC.

Local recurrence after radical NU regardless of approach is rare. Ribal et $\mathrm{al}^{45}$ reported that local recurrence rate after laparoscopic NU ranges from $4 \%$ to $15 \%$, similar to that in open NU. Lim et $\mathrm{al}^{46}$ described their single-center experience with intermediate-term oncological outcomes in 32 patients and a mean follow-up duration of 45.5 months, reporting a local recurrence rate of $12.5 \%$, while Aboumohamed et al reported a local recurrence rate of $8.3 \%{ }^{42}$ This appears comparable to that of other approaches, further supporting the oncological equivalency of the robotic approach. Reported bladder recurrence rates of the ten RALNU studies ranged from $0 \%$ to $44 \%$ after a follow-up of between 6 months and 15.2 months, with contemporary studies reporting recurrence rates between $14 \%$ and $22 \%$ after a follow-up of 8-14.7 months.

After NU, factors affecting the risk of distant metastasis include the stage and grade of the tumor. A significant proportion of patients with UTUC do develop distant metastasis following radical treatment. Tanaka et $\mathrm{al}^{47}$ found that $38.5 \%$ of patients develop distant metastasis despite radical NU with the main sites of metastasis being that of the lung, liver, and bone.

Rates of distant metastases in open NU and laparoscopic NU series ranged from $11 \%$ to $35 \%$ and $10 \%$ to $28 \%$, respectively. ${ }^{46}$ There is a tendency toward equivalent oncological outcomes after laparoscopic or open NU. In a meta-analysis of the studies comparing laparoscopic NU and open NU reporting distant metastasis, Rai et $\mathrm{al}^{40}$ reported that results favored the laparoscopic group; however, when adjusted for confounding factors particularly stage and grade, both approaches showed consistent oncological equivalence. Stewart et $\mathrm{al}^{43}$ reported no difference in terms of overall survival, progression-free survival, and cancerspecific survival between laparoscopic NU and open radical NU after long-term follow-up of 13 years. Only grade and stage of the tumor were found to have an impact on the progression-free survival and cancer-specific survival. Studies reporting intermediate outcomes after RALNU showed distant metastasis rates of $13.3 \%-31.3 \%$ and appeared to be in line with different data in the literature on the open and laparoscopic approaches.
Fundamental oncological principles, such as avoiding tumor spillage, especially in cases of transitional cell carcinomas and resection within a closed system, must be strictly adhered to, irrespective of the surgical approach. Caution should be exercised during RALNU, especially for patients with high-stage disease. Optimal surgical exposure and maneuverability of robotic instruments are crucial when performing RALNU and cannot be compromised even if these require additional port placements or repositioning of patient.

It is difficult to avoid tumor spillage and seeding in minimally invasive surgeries. The improved ergonomics and greater degrees of freedom that the robot provides facilitate the dissection of the distal ureter and bladder cuff. Nevertheless, the advantages that robotic assistance offers will need to be translated into improved clinical outcomes for patients with UTUC, in terms of both short-term morbidity and longterm survival outcomes. This issue will become clearer in the future with the increase in RALNU being performed and when longer term data are available. Although open radical $\mathrm{NU}$ is still considered to be the gold standard in advanced UTUC, there is no doubt that it is slowly losing ground.

\section{Cost effectiveness}

Many studies have demonstrated a higher cost associated with RALNU when compared to both the laparoscopic and open approaches. Despite favorable perioperative outcomes and complication rates, RALNU has been found in populationbased assessment studies to generate cost above the 75th percentile of the pre-propensity score population compared to $15 \%$ for hospitalization for laparoscopic NU. ${ }^{41}$ However, most studies looking at perioperative costs associated with these minimally invasive approaches are limited to hospitalization costs. More comprehensive cost efficacy studies and analysis of the impact on quality of life data are still lacking, limiting conclusions on cost effectiveness of RALNU at this point in time.

\section{Conclusion}

RALNU has emerged as a novel minimally invasive alternative to laparoscopic and open NU and has demonstrated promising early results. With experience and progress in the technology of the da Vinci robotic system, the need for intraoperative redocking or repositioning of the patients is reduced. However, RALNU is still lacking long-term reports on perioperative and oncological outcomes, even though intermediate outcomes and analyses have shown oncological equivalency when compared to other approaches. 
Cost efficacy studies and quality of life analysis are required to justify the higher non-negligible costs associated with RALNU.

\section{Disclosure}

The authors report no conflicts of interest in this work.

\section{References}

1. Clayman RV, Kavoussi LR, Figenshau RS, Chandhoke PS, Albala DM. Laparoscopic nephroureterectomy: initial clinical case report. J Laparoendosc Surg. 1991;1(6):343-349.

2. Patel MN, Aboumohamed A, Hemal A. Does transition from the da Vinci Si to Xi robotic platform impact single-docking technique for robot-assisted laparoscopic nephroureterectomy? BJU Int. 2015;116(6): 990-994.

3. Darwiche F, Swain S, Kallingal G, et al. Operative technique and early experience for robotic-assisted laparoscopic nephroureterectomy (RALNU) using da Vinci Xi. Springerplus. 2015;4:298.

4. Lai G-S, Yang C-K, Ou Y-C, et al. Robot assisted nephroureterectomy for upper urinary tract urothelial carcinoma without intraoperative reposition or redocking. Urological Science. 2015.

5. Yang CK, Chung SD, Hung SF, et al. Robot-assisted nephroureterectomy for upper tract urothelial carcinoma: the Taiwan Robot Urological Surgery Team (TRUST) experience. World J Surg Oncol. 2014;12(1):219

6. Zargar H, Krishnan J, Autorino R, et al. Robotic nephroureterectomy: a simplified approach requiring no patient repositioning or robot redocking. Eur Urol. 2014;66(4):769-777.

7. Badani KK, Rothberg MB, Bergman A, et al. Robot-assisted nephroureterectomy and bladder cuff excision without patient or robot repositioning: description of modified port placement and technique. J Laparoendosc Adv Surg Tech A. 2014;24(9):647-650.

8. Pugh J, Parekattil S, Willis D, Stifelman M, Hemal A, Su LM. Perioperative outcomes of robot-assisted nephroureterectomy for upper urinary tract urothelial carcinoma: a multi-institutional series. BJU Int. 2013;112(4):E295-E300.

9. Khanna R, Stein RJ, White MA, et al. Single institution experience with robot-assisted laparoendoscopic single-site renal procedures. J Endourol. 2012;26(3):230-234.

10. Won Lee J, Arkoncel FR, Rha KH, et al. Urologic robot-assisted laparoendoscopic single-site surgery using a homemade single-port device: a single-center experience of 68 cases. $J$ Endourol. 2011;25(9): 1481-1485.

11. Lee Z, Cadillo-Chavez R, Lee DI, Llukani E, Eun D. The technique of single stage pure robotic nephroureterectomy. J Endourol. 2013; 27(2):189-195.

12. Hemal AK, Stansel I, Babbar P, Patel M. Robotic-assisted nephroureterectomy and bladder cuff excision without intraoperative repositioning. Urology. 2011;78(2):357-364.

13. Eandi JA, Nelson RA, Wilson TG, Josephson DY. Oncologic outcomes for complete robot-assisted laparoscopic management of upper-tract transitional cell carcinoma. $J$ Endourol. 2010;24(6):969-975.

14. Park SY, Jeong W, Ham WS, Kim WT, Rha KH. Initial experience of robotic nephroureterectomy: a hybrid-port technique. BJU Int. 2009;104(11):1718-1721.

15. Hu JC, Silletti JP, Williams SB. Initial experience with robot-assisted minimally-invasive nephroureterectomy. J Endourol. 2008;22(4): 699-704.

16. Eun D, Bhandari A, Boris R, Rogers C, Bhandari M, Menon M. Concurrent upper and lower urinary tract robotic surgery: strategies for success. BJU Int. 2007;100(5):1121-1125.

17. Nanigian DK, Smith W, Ellison LM. Robot-assisted laparoscopic nephroureterectomy. $J$ Endourol. 2006;20(7):463-466.
18. Rose K, Khan S, Godbole H, Olsburgh J, Dasgupta P; GUY'S and St. Thomas' Robotics Group. Robotic assisted retroperitoneoscopic nephroureterectomy - first experience and the hybrid port technique. Int J Clin Pract. 2006;60(1):12-14.

19. Lim SK, Shin TY, Rha KH. Current status of robot assisted laparoscopic radical nephroureterectomy for management of upper tract urothelial carcinoma. Curr Urol Rep. 2013;14(2):138-146.

20. Lim SK, Shin TY, Kim KH, et al. Laparoendoscopic single-site (LESS) robot-assisted nephroureterectomy: comparison with conventional multiport technique in the management of upper urinary tract urothelial carcinoma. BJU Int. 2014;114(1):90-97.

21. Roscigno M, Brausi M, Heidenreich A, et al. Lymphadenectomy at the time of nephroureterectomy for upper tract urothelial cancer. Eur Urol. 2011;60(4):776-783.

22. Roscigno M, Shariat SF, Margulis V, et al. The extent of lymphadenectomy seems to be associated with better survival in patients with nonmetastatic upper-tract urothelial carcinoma: how many lymph nodes should be removed? Eur Urol. 2009;56(3):512-518.

23. Kondo T, Hara I, Takagi T, et al. Possible role of template-based lymphadenectomy in reducing the risk of regional node recurrence after nephroureterectomy in patients with renal pelvic cancer. Jpn $J$ Clin Oncol. 2014;44(12):1233-1238.

24. Abouassaly R, Alibhai SM, Shah N, Timilshina N, Fleshner N, Finelli A. Troubling outcomes from population-level analysis of surgery for upper tract urothelial carcinoma. Urology. 2010;76(4):895-901.

25. Joniau S, Van Cleynenbreugel B, Blyweert W, Romics I, Van Poppel H. Is radical nephroureterectomy and lymph node dissection necessary for upper tract TCC. Eur Urol Suppl. 2010;9:442-445.

26. Rouprêt M, Babjuk M, Compérat E, et al. European association of urology guidelines on upper urinary tract urothelial cell carcinoma: 2015 update. Eur Urol. 2015;68(5):868-879.

27. Kondo T, Takagi T, Tanabe K. Therapeutic role of template-based lymphadenectomy in urothelial carcinoma of the upper urinary tract. World J Clin Oncol. 2015;6(6):237-251.

28. Yang D, Chen Q, Song X, et al. Effect of lymph node dissection on the outcomes of upper tract urothelial carcinomas: a meta-analysis. Expert Rev Anticancer Ther. 2014;14(6):667-675.

29. Mathieu R, Bensalah K, Lucca I, Mbeutcha A, Rouprêt M, Shariat SF. Upper urinary tract disease: what we know today and unmet needs. Transl Androl Urol. 2015;4(3):261-272.

30. Pearce SM, Pariser JJ, Patel SG, Steinberg GD, Shalhav AL, Smith ND. The effect of surgical approach on performance of lymphadenectomy and perioperative morbidity for radical nephroureterectomy. Urol Oncol. 2016;34(3):121.e15-121.e21.

31. Ambani SN, Weizer AZ, Wolf JS Jr, He C, Miller DC, Montgomery JS Matched comparison of robotic vs laparoscopic nephroureterectomy: an initial experience. Urology. 2014;83(2):345-349.

32. Srirangam SJ, Van Cleynenbreugel B, Van Poppel H. Laparoscopic nephroureterectomy: the distal ureteral dilemma. Adv Urol. 2009;2009:1-9.

33. Li WM, Shen JT, Li CC, et al. Oncologic outcomes following three different approaches to the distal ureter and bladder cuff in nephroureterectomy for primary upper urinary tract urothelial carcinoma. Eur Urol. 2010;57(6):963-969.

34. Walton TJ, Sherwood BT, Parkinson RJ, et al. Comparative outcomes following endoscopic ureteral detachment and formal bladder cuff excision in open nephroureterectomy for upper urinary tract transitional cell carcinoma. J Urol. 2009;181(2):532-539.

35. Xylinas E, Rink M, Cha EK, et al. Impact of distal ureter management on oncologic outcomes following radical nephroureterectomy for upper tract urothelial carcinoma. Eur Urol. 2014;65(1):210-217.

36. Phé V, Cussenot O, Bitker MO, Rouprêt M. Does the surgical technique for management of the distal ureter influence the outcome after nephroureterectomy? BJU Int. 2011;108(1):130-138.

37. Tsivian A, Benjamin S, Sidi AA. A sealed laparoscopic nephroureterectomy: a new technique. Eur Urol. 2007;52(4):1015-1019. 
38. Ritch CR, Kearns JT, Mues AC, et al. Comparison of distal ureteral management strategies during laparoscopic nephroureterectomy. J Endourol. 2011;25(7):1149-1154.

39. Hu CY, Yang CK, Huang CY, et al. Robot-assisted laparoscopic nephroureterectomy versus hand-assisted laparoscopic nephroureterectomy for upper urinary tract urothelial carcinoma: a matched comparison study. Biomed Res Int. 2015;2015:1-7.

40. Rai BP, Shelley M, Coles B, Somani B, Nabi G. Surgical management for upper urinary tract transitional cell carcinoma (UUT-TCC): a systematic review. BJU Int. 2012;110(10):1426-1435.

41. Trudeau V, Gandaglia G, Shiffmann J, et al. Robot assisted versus laparoscopic nephroureterectomy for upper-tract urothelial cancer: a population-based assessment of costs and perioperative outcomes. Can Urol Assoc J. 2014;8(9-10):E695-E701.

42. Aboumohamed AA, Krane LS, Hemal AK. Oncologic outcomes following robot-assisted laparoscopic nephroureterectomy with bladder cuff excision for upper tract urothelial carcinoma. J Urol. 2015;194(6):1561-1566.
43. Stewart GD, Humphries KJ, Cutress ML, Riddick AC, McNeill SA, Tolley DA. Long-term comparative outcomes of open versus laparoscopic nephroureterectomy for upper urinary tract urothelial-cell carcinoma after a median follow-up of 13 years. J Endourol. 2011; 25(8):1329-1335.

44. Ito A, Shintaku I, Satoh M, et al. Intravesical seeding of upper urinary tract urothelial carcinoma cells during nephroureterectomy: an exploratory analysis from the THPMG trial. Jpn J Clin Oncol. 2013;43(11): 1139-1144.

45. Ribal MJ, Huguet J, Alcaraz A. Oncologic outcomes obtained after laparoscopic, robotic and/or single port nephroureterectomy for upper urinary tract tumours. World J Urol. 2013;31(1):93-107.

46. Lim SK, Shin TY, Kim KH, et al. Intermediate-term outcomes of robot-assisted laparoscopic nephroureterectomy in upper urinary tract urothelial carcinoma. Clin Genitourin Cancer. 2013;11(4):515-521.

47. Tanaka N, Kikuchi E, Kanao K, et al. Metastatic behavior of upper tract urothelial carcinoma after radical nephroureterectomy: association with primary tumor location. Ann Surg Oncol. 2014;21(3):1038-1045.
Robotic Surgery: Research and Reviews

\section{Publish your work in this journal}

Robotic Surgery: Research and Reviews is an international, peer reviewed, open access, online journal publishing original research, commentaries, reports, and reviews on the theory, use and application of robotics in surgical interventions. Articles on the use of supervisory-controlled robotic systems, telesurgical devices, and shared-control systems are

\section{Dovepress}

invited. The manuscript management system is completely online and includes a very quick and fair peer review system, which is all easy to use. Visit http://www.dovepress.com/testimonials.php to read real quotes from published authors. 